\title{
ACQUISITION OF STUDENT SCIENTIFIC INQUIRY SKILLS: CENTRALISED EXAMINATION RESULTS IN CHEMISTRY
}

\author{
Jelena Volkinsteine \\ Faculty of Chemistry, University of Latvia, Latvia \\ Dace Namsone \\ Centre for Science and Mathematics Education, University of Latvia, Latvia
}

\begin{abstract}
From 2011, the new educational standard in Latvia in the framework of the educational reform on the centralised examination $(C E)$ in chemistry stipulates students to demonstrate the inquiry skills they have mastered. The purpose of this study is to find out the students' inquiry skills by analysing the CE results in chemistry. This study addresses the following research questions: (a) To what extent are the centralised examination inquiry skills measured according to the standard outcomes? (b) What information on how students have mastered the inquiry skills in chemistry is available from the CE results for the period of 2011-2015? (c) Does measuring the inquiry skills using inquiry-based laboratory work and inquiry tasks demonstrate similar achievements? The results of the study show that the CE inquiry tasks allow examining only several inquiry skills, that students have difficulties in hypothesizing and planning the procedure. The results of the examination inquiry task (the 'hidden' part) and inquiry-based laboratory work (the part prepared by the school) differ considerably. These findings show a contradiction. On the one hand, when carrying out a inquiry-based laboratory work at school students demonstrate good inquiry skills. On the other hand, they lack the skills when solving an inquiry task during the centralised examination. This proves the insufficient skills of the teachers in organising real student scientific inquiry during lessons and failure in using the inquiry-based laboratory work record as an objective measuring tool in evaluating the student inquiry skills in the examination, which is our case.
\end{abstract}

Keywords: centralised examination; scientific inquiry; inquiry skills; inquiry-based laboratory work.

\section{Introduction}

Nowadays many scientists consider student scientific inquiry as the main feature characterising the natural sciences learning process at school in general (Abd-El-Khalick et al., 2004; Aikenhead, 2006; Савенков, 2006). For instance, in the USA, in the late 20s, the understanding of ,, a good natural science teaching and learning process" is being increasingly linked to the notion of 'scientific inquiry' (Anderson, 2002).

Initially, the notion 'scientific inquiry' was used in order to motivate students to inquire about the surrounding world in the study process exactly in 
the same manner as scientists do (Dewey, 1910; Schwab, 1960), currently 'scientific inquiry' is understood as a multi-dimensional process expanding in time and space.

Scientists accentuate different aspects of scientific activity and by this notion link the role of a student as an active participant of the inquiry process with a procedure established in science using which it is possible to find the answer to the creative task, i.e., which solution route is not known in advance, revealing the dual nature of the notion 'scientific inquiry': on the one hand, inquiry is attributable to teaching methods and learning strategies, and on the other hand, those are the learning outcomes that a student should know, understand and be able to do (Anderson, 2002; Minstrell \& van Zee, 2000; Hackett, 1998; Chiappetta, 1997).

In the study process, the scientific inquiry amplitude is quite wide and may vary from a more student-activity-focused scientific inquiry to a more teacheractivity-focused scientific inquiry. Therefore experts talk about different ways how a student's mind can progress towards the direction of more scientific thinking, and about different levels of inquiry (Hegarty - Hazel, 1990; MartinHansen, 2002; Brown et al., 2006; Buck et al., 2008; Sadeh \& Zion, 2009).

Scientific inquiry is based on three categories: question (problem), procedure (method and means) and conclusions (answers). These categories are called as given, if the students are provided instructions, and open, if no instructions are provided. Category changes and 'the level of openness' lead to 4 levels of inquiry: confirmation, structured, guided and open inquiry (Schwab, 1962; Herron, 1971).

Buck, Bretz and Towns analysed inquiry-based laboratory work (ILW) content and elaborated scientific inquiry classification based on six categories: problem/question, theory/background, procedures/design, result analysis, result communication, and conclusions (Buck et al., 2008). For instance, according to their classification, only two out of the six categories are provided in open inquiry: problem/question and theory/background.

ILWs allow developing such student inquiry skills as proposing the research question, formulating a hypothesis, developing and carrying out an experiment, and scientific explanation formulation and communication using scientific arguments (Hofstein et al., 2005; Krajcik et al., 2001).

The variety of interpretation of the notion 'inquiry skills', including the variable, sequence and relative importance, in place in the local, regional and national science educational standards is confusing (Hanauer et al., 2006; Harlen \& Jelly, 1989/1997). Many didactics experts pay the greatest attention to less complicated inquiry skills. Besides, others believe that the final destination of sciences should be formation of scientific literacy that on its own envisages development of the higher degree inquiry skills would (Wenning, 2005). 
Teachers and their students require information on development of the inquiry skills during the study process and the need to know on what level they have been acquired. The problem is that ,inquiry is difficult to assess in a onetime test. A teacher's position in the classroom allows for personal judgements of one's abilities over extended investigation that cannot be matched by any feasible external testing procedure" (National Research Council, 2001). Therefore multiple assessment measures such as constructed response questions, performance tasks, portfolios, etc., should be used.

Some countries have accumulated a rich experience on how inquiry skill assessment can be organised at the end of a particular education stage, have detailed instructions in place on how to develop inquiry tasks, organise scientific inquiry assessment procedure, including the time, number of tasks, assessment levels, description of criterion and point system (NECAP Science Assessment, 2008; AQA Science Controlled Assessment in GCSE, 2014). It should be noted that the approach to assessing the inquiry skills in an exam differs by country. For instance, those are rare cases when the experiment part is also included in the examination, as it is at Cambridge international examinations. Also the OECD's International Programme for Student Assessment (PISA) developed tasks and an approach on how to measure the ability to ,, explain phenomena scientifically, evaluate and design scientific enquiry, and interpret data and evidence scientifically" (OECD, 2015).

Since 2005, within the framework of the education reform in Latvia, the new standards for chemistry subjects were developed both for the basic and general upper-secondary education (the Republic of Latvia Cabinet Regulations No 281 of 2013). The new subject standards contain a curriculum component „Scientific inquiry” that includes:

- $\quad$ Posing the research question (RQ) and planning the procedure;

- Data collecting and recording;

- Data processing;

- Data and result analysis and evaluation;

- Communicative activity and collaboration. Consequently, the national educational documents stipulate that upon graduating a secondary school the students should have the inquiry skills developed.

For the purpose of identifying the level of mastering the inquiry skills, from 2011, a inquiry task (hereinafter task 3.3 ) was introduced in Part 3 of the centralised examination (CE) in chemistry organised by the National Centre for Education (NCE), and Part 4 is a inquiry-based laboratory work (ILW) report (Table 1). 
Jelena Volkinsteine, Dace Namsone. Acquisition of Student Scientific Inquiry Skills: Centralised Examination Results in Chemistry

Table 1 Ratio of the Examination Parts (NCE, 2015)

\begin{tabular}{|l|l|l|l|l|}
\hline $\begin{array}{l}\text { Part } \\
\text { (Cognitive Level) }\end{array}$ & $\begin{array}{l}\text { Number } \\
\text { of Tasks }\end{array}$ & $\begin{array}{l}\text { Max. Number } \\
\text { of Points }\end{array}$ & $\begin{array}{l}\text { Part } \\
\text { Ratio, \% }\end{array}$ & $\begin{array}{l}\text { Completion } \\
\text { Time, Min }\end{array}$ \\
\hline 1 Knowledge and basic skills & 30 & 30 & 40 & 45 \\
\hline $\begin{array}{l}\text { 2 Knowledge application in } \\
\text { standard situations }\end{array}$ & 10 & 24 & 32 & 60 \\
\hline $\begin{array}{l}\text { 3 Knowledge application in } \\
\text { non-standard situations }\end{array}$ & 3 & 15 & 20 & 75 \\
\hline 4 ILW (Carried out at school) & 2 & $24 \cdot 0.25=6$ & 8 & \\
\hline
\end{tabular}

Over a period of five years inquiry skills were studied using Task 3.3 (Table 2), and the ILW.

Table 2 Inquiry Skills Assessed According to Task 3.3 at the CE in 2011 - 2015

\begin{tabular}{|c|c|c|c|}
\hline $\begin{array}{l}\text { Inquiry } \\
\text { Steps }\end{array}$ & $\begin{array}{l}\text { Posing the Research Question } \\
\text { and Planning the Procedure }\end{array}$ & $\begin{array}{l}\text { Data Collecting } \\
\text { and Recording }\end{array}$ & $\begin{array}{l}\text { Data Analysis } \\
\text { and Evaluation }\end{array}$ \\
\hline 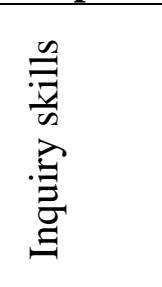 & $\begin{array}{l}\text { - Identifies and formulates the } \\
\text { research question/hypothesis } \\
\text { - Identifies and groups variables } \\
\text { - Identifies materials and } \\
\text { equipment } \\
\text { - Plans the procedure }\end{array}$ & $\begin{array}{l}\text { - Elaborates a } \\
\text { data collection } \\
\text { table }\end{array}$ & $\begin{array}{l}\text { - Evaluates the } \\
\text { experiment } \\
\text { - Draws } \\
\text { conclusions }\end{array}$ \\
\hline
\end{tabular}

Two key criteria exist according to which we can deliberate on the quality of the tests, CE and ILW: reliability and validity. A good measuring instrument should be both reliable and valid. The test has acquired the reliability guarantee by rechecking it. The reliability refers to the degree at which the student results in one test are more or less the same as the results that are obtained in reassessment.

The reliability is important, but the most important is for a test to be valid, so that the CE inquiry task and ILW would measure what they are supposed to measure - the inquiry skills of the students. Important test validity types are content, criterion, and construct validity. The content validity can be established by the help of independent experts. A test is suitable for forecasting which students will work successfully according to the desired criteria. The construct validity refers to the questions whether a test measures exactly the variable it is purported to measure, whether it results in understandable interpretations and the consequences of use thereof are acceptable (Cohen et al., 2011).

The purpose of this study is to find out the students' inquiry skills by analysing the CE results in chemistry. This study addresses the following research questions: (a) To what extent are the centralised examination inquiry skills measured according to the standard outcomes? (b) What information on 
how students have mastered the inquiry skills in chemistry is available from the CE results for the period of 2011-2015? (c) Does measuring the inquiry skills using inquiry-based laboratory work and inquiry tasks demonstrate similar achievements?

\section{Methodology Research methods}

- Analysis of the CE examination papers (over the period from 2011 to 2015).

- $\quad$ Analysis of the student CE work tasks (over the period from 2011 to 2015).

- Analysis of the ILW records submitted by schools (over the period from 2011 to 2015).

- $\quad$ Analysis of the CE results (over the period from 2011 to 2015).

All in all, 720 student CE works and the same number of student ILW records were reviewed.

All the CE data on the acquisition of inquiry skills by students were processed with Item and Test Analysis Program - ITEMAN for Windows 95 Version 3.50 and developed in a SQL server, MS Excel features (PivotTable) were used for processing the selected data and compiling a table.

\section{Study Scope Characterisation}

The CE was voluntarily taken by students (Table 3) from different schools: state grammar schools, grammar schools, upper-secondary schools, vocational and art schools, special and boarding schools located in the capital Riga, other cities and rural territories of Latvia.

Table 3 Number of Study Respondents

\begin{tabular}{|l|c|c|c|c|c|}
\hline CE Year & 2011 & 2012 & 2013 & 2014 & 2015 \\
\hline Number of Students & 896 & 665 & 535 & 561 & 528 \\
\hline
\end{tabular}

\section{CE Duration Time Procedure}

Form 12 students who chose to take the chemistry examination received workbooks, record code and additional tasks to be completed within 3 hours. The completed works were collected, and records of 2 ILW developed earlier at school were attached and delivered for assessment to the NCE. 
Jelena Volkinsteine, Dace Namsone. Acquisition of Student Scientific Inquiry Skills: Centralised Examination Results in Chemistry

\section{CE Task 3.3 and ILW Description and Assessment Procedure}

Task 3.3 is a structured inquiry task, it contains a scenario which context is related to the real life, and test elements that examine certain inquiry skills, e.g., formulates the hypothesis (Table 4).

\section{Table 4 Fragment of task 3.3 of the $\mathrm{CE}$ in 2011}

Read the text and do what is required.

Milk is a mixture containing many different substances, including, protein, amino acids and lactic acid. The concentration of amino acids varies in fresh milk and cultured products because it is gradually changing during the acidification process.

Formulate the research problem using the information provided in the scenario!

Formulate the hypothesis, including the independent variable, dependent variable and justification! Plan an experiment for proving your hypothesis in a laboratory!

Task 3.3 was characterized, using the ILW classification approach (Buck et al., 2008), (Table 5).

Table 5 Task 3.3 Characteristics at the CE in 2011 - 2015

\begin{tabular}{|c|c|c|c|c|c|}
\hline \multicolumn{6}{|c|}{ Year 2011} \\
\hline $\begin{array}{l}\text { Charac- } \\
\text { teristic }\end{array}$ & $\begin{array}{l}\text { Problem/ } \\
\text { question }\end{array}$ & $\begin{array}{c}\text { Theory/ } \\
\text { background }\end{array}$ & Procedures/design & $\begin{array}{l}\text { Results } \\
\text { analysis }\end{array}$ & Conclusions \\
\hline $\begin{array}{l}\text { Open } \\
\text { inquiry }\end{array}$ & $\begin{array}{l}\text { not } \\
\text { provided }\end{array}$ & provided & not provided & $\begin{array}{l}\text { not } \\
\text { provided }\end{array}$ & not provided \\
\hline Skills & \multicolumn{5}{|c|}{$\begin{array}{ll}\text { - Identifies the RQ } & \text { - Identifies materials to use } \\
\text { - Identifies variables } & \text { - Plans the procedure } \\
\text { - Formulates the H } & \end{array}$} \\
\hline \multicolumn{6}{|c|}{ Year 2012} \\
\hline $\begin{array}{l}\text { Charac- } \\
\text { teristic }\end{array}$ & $\begin{array}{l}\text { Problem/ } \\
\text { question }\end{array}$ & $\begin{array}{c}\text { Theory/ } \\
\text { background }\end{array}$ & $\begin{array}{l}\text { Procedures/desig } \\
n\end{array}$ & $\begin{array}{l}\text { Results } \\
\text { analysis }\end{array}$ & Conclusions \\
\hline $\begin{array}{l}\text { Open } \\
\text { inquiry }\end{array}$ & $\begin{array}{l}\text { not } \\
\text { provided }\end{array}$ & provided & not provided & $\begin{array}{l}\text { not } \\
\text { provided }\end{array}$ & not provided \\
\hline Skills & \multicolumn{4}{|c|}{$\begin{array}{ll}\text { - Identifies the RQ } & \text { - Identifies materials to use } \\
\text { - Identifies variables } & \text { - Plans the procedure } \\
\text { - Formulates the H } & \end{array}$} & \\
\hline \multicolumn{6}{|c|}{ Year 2013} \\
\hline $\begin{array}{l}\text { Charac- } \\
\text { teristic }\end{array}$ & $\begin{array}{l}\text { Problem/ } \\
\text { question }\end{array}$ & $\begin{array}{c}\text { Theory/ } \\
\text { background }\end{array}$ & Procedures/design & Results analysis & Conclusions \\
\hline $\begin{array}{l}\text { Open } \\
\text { inquiry }\end{array}$ & provided & provided & not provided & not provided & not provided \\
\hline Skills & & & $\begin{array}{l}\text { - Identifies materia } \\
\text { - Plans the procedu } \\
\text { - Elaborates a data }\end{array}$ & use & \\
\hline
\end{tabular}




\begin{tabular}{|c|c|c|c|c|c|}
\hline \multicolumn{6}{|c|}{ Year 2014} \\
\hline $\begin{array}{l}\text { Charac- } \\
\text { teristic }\end{array}$ & $\begin{array}{l}\text { Problem/ } \\
\text { question }\end{array}$ & $\begin{array}{c}\text { Theory/ } \\
\text { background }\end{array}$ & Procedures/design & $\begin{array}{l}\text { Results } \\
\text { analysis }\end{array}$ & Conclusions \\
\hline $\begin{array}{l}\text { Guided } \\
\text { inquiry }\end{array}$ & provided & provided & provided & $\begin{array}{l}\text { not } \\
\text { provided }\end{array}$ & not provided \\
\hline Skills & \multicolumn{5}{|c|}{$\begin{array}{r}\text { - Evaluates the experiment } \\
\text { - Draws conclusions }\end{array}$} \\
\hline \multicolumn{6}{|c|}{ Year 2015} \\
\hline $\begin{array}{l}\text { Charac- } \\
\text { teristic }\end{array}$ & $\begin{array}{l}\text { Problem/ } \\
\text { question }\end{array}$ & $\begin{array}{c}\text { Theory/ } \\
\text { background }\end{array}$ & Procedures/design & $\begin{array}{l}\text { Results } \\
\text { analysis }\end{array}$ & Conclusions \\
\hline $\begin{array}{l}\text { Open } \\
\text { inquiry }\end{array}$ & provided & provided & not provided & $\begin{array}{l}\text { not } \\
\text { provided }\end{array}$ & not provided \\
\hline Skills & \multicolumn{5}{|c|}{$\begin{array}{l}\text { - Identifies variables } \\
\text { - Identifies materials to use } \\
\text { - Plans the procedure } \\
\text { - Elaborates a data collection table }\end{array}$} \\
\hline
\end{tabular}

Each of the ILWs to be submitted with the examination paper consists of the following parts: an assignment given by the teacher, work description filled in by the student, assessment record (elaborated by the teacher according to the criteria developed by the NCE).

The student inquiry skills (the CE task 3.3 and ILW record) were assessed in three levels according to defined criteria (see example in Table 6). The assessment is carried out by 21 specially trained external experts.

The assessment (in points) of each laboratory work in the examination is made of: Experimental skill assessment carried out by the teacher by observing the student's activity while performing the laboratory work. The CE assessor enters this in the assessment record. Inquiry skill assessment performed by the $\mathrm{CE}$ assessor according to the work description filled in by the student.

Table 6 Example of the Assessment Criteria for the Inquiry Skill „Plans the procedure” (NCE, 2015)

\begin{tabular}{|c|c|c|c|}
\hline Lev & $\begin{array}{r}\text { Con } \\
2 \mathrm{p} \\
\end{array}$ & $\begin{array}{l}\text { Par } \\
1 \mathrm{pc}\end{array}$ & $\begin{array}{c}\text { No } \\
0 \text { points } \\
\end{array}$ \\
\hline 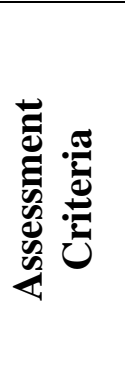 & $\begin{array}{l}\text { Describes the sequence of } \\
\text { actions for identifying } \\
\text { variables and/or features, using } \\
\text { the chosen materials and } \\
\text { equipment for the purpose of } \\
\text { obtaining sufficient and } \\
\text { reliable data. Envisages } \\
\text { meeting the safety rules. }\end{array}$ & $\begin{array}{l}\text { Incompletely describes the } \\
\text { sequence of actions for } \\
\text { obtaining sufficient and } \\
\text { reliable data, identifying } \\
\text { the materials and } \\
\text { equipment or does not } \\
\text { envisage meeting any } \\
\text { safety rules. }\end{array}$ & $\begin{array}{l}\text { Writes separate } \\
\text { steps of the } \\
\text { procedure plan } \\
\text { or the described } \\
\text { procedure plan is } \\
\text { unsuitable for } \\
\text { obtaining any } \\
\text { data. }\end{array}$ \\
\hline
\end{tabular}


Jelena Volkinsteine, Dace Namsone. Acquisition of Student Scientific Inquiry Skills: Centralised Examination Results in Chemistry

\section{Results}

\section{Student Success Rate in Mastering Inquiry Skills. Task 3.3}

The CE results show that task 3.3 is difficult for the students and their success rate fluctuates between $28.5 \%$ and $56.5 \%$ (Table 7). The students demonstrated lower results in the inquiry task comparing with the results in part 3 and the CE in general, especially in 2011, 2013 and 2015.

Table 7 Student Success Rate in CE in 2011 - 2015

\begin{tabular}{|c|c|c|c|c|c|c|}
\hline Year & In General & Part 3 & \multicolumn{4}{|c|}{ Task 3.3 } \\
\cline { 2 - 7 } & $\begin{array}{c}\text { Success } \\
\text { Rate, \% }\end{array}$ & $\begin{array}{c}\text { Success } \\
\text { Rate, \% }\end{array}$ & $\begin{array}{c}\text { Number of } \\
\text { Mean Points }\end{array}$ & $\begin{array}{c}\text { Standard } \\
\text { Deviation }\end{array}$ & $\begin{array}{c}\text { Max. } \\
\text { Number } \\
\text { of Points }\end{array}$ & $\begin{array}{c}\text { Success } \\
\text { Rate, \% }\end{array}$ \\
\hline 2011 & 61.3 & 36.5 & 2.281808036 & 1.280534748 & 8 & 28.5 \\
\hline 2012 & 59.3 & 44.7 & 2.853383459 & 1.596284696 & 6 & 47.6 \\
\hline 2013 & 67.7 & 35.9 & 2.014018692 & 1.696904463 & 6 & 33.6 \\
\hline 2014 & 59.5 & 46.7 & 3.389483066 & 1.457522329 & 6 & 56.5 \\
\hline 2015 & 62.6 & 46.0 & 1.902462121 & 1.540550432 & 6 & 31.7 \\
\hline
\end{tabular}

It should be noted that more detailed results show that the students have unevenly mastered the inquiry skills tested in the inquiry task. The majority of the students who took the exam did not have any difficulties in identifying and formulating the research question - the success rate exceeds $80 \%$. In 2011, the question on identifying materials and equipment to use has been very difficult for the students - the success rate is merely $11 \%$, compared to the success rate of $68 \%$ in 2015. Nevertheless, the students are still struggling with the procedure plan and data collection table - the success rate does not exceed $35 \%$ (Table 8).

Table 8 Inquiry Skills Mastered by Students According to the Results of Task 3.3

\begin{tabular}{|l|l|l|l|l|}
\hline \multirow{2}{*}{ Skills Tested by the Task } & \multicolumn{4}{c|}{ Success Rate, \% } \\
\cline { 2 - 5 } & $\mathbf{2 0 1 5}$ & $\mathbf{2 0 1 3}$ & $\mathbf{2 0 1 2}$ & $\mathbf{2 0 1 1}$ \\
\hline $\begin{array}{l}\text { Identifies and formulates the research } \\
\text { question }\end{array}$ & not tested & not tested & 81 & 89 \\
\hline Formulates the hypothesis & not tested & not tested & 47 & 44 \\
\hline Identifies and groups variables & 33 & no data & no data & no data \\
\hline Identifies materials and equipment & 68 & 50 & 42 & 11 \\
\hline Plans the procedure & 22 & 31 & 35 & 5 \\
\hline Elaborates a data collection table & 26 & 22 & $\begin{array}{l}\text { not } \\
\text { tested }\end{array}$ & $\begin{array}{l}\text { not } \\
\text { tested }\end{array}$ \\
\hline
\end{tabular}

Let us look below at the characteristic mistakes made by the students. 


\section{Inquiry Skill „Identifies and formulates the research question”}

- The research question is written generally, unclearly or the research question envisages the answer to be in the form of a number. Example extracts from student CE works (E): How to stabilise hydrogen peroxide decomposition for obtaining oxygen?; How high is amino acid concentration in dairy products?

- It is difficult or even impossible to test the research question by experimental means. E: Why can't uniform decomposition of $\mathrm{H}_{2} \mathrm{O}_{2}$ be ensured?

- The answer to the research question can be found in the situation text. E: Does fermentation influence the amino acid concentration in dairy products?

\section{Inquiry Skill „Formulates the Hypothesis”}

- The hypothesis does not give the answer to the research question. E: If $\mathrm{H}_{2} \mathrm{O}_{2}$ of different concentration are used the decomposition time will be different. (The research question: Why can't uniform decomposition of $\mathrm{H}_{2} \mathrm{O}_{2}$ be ensured?)

- The hypothesis does not contain any variable/ies. E: If hydrogen peroxide solutions of various concentrations are decomposed at the presence of a catalyser, oxygen can be obtained.

- The hypothesis formulation looks like a guess. E: If $\mathrm{MnO}_{2}$ is added when decomposing the hydrogen peroxide, the chemical reaction speed will be approximately 5.

- It does not say how exactly the dependent variable will change. E: If a bacteria strain is added to fresh air, the amino acid concentration will change during the fermentation process.

- The hypothesis does not contain a justification or it is not logical. E: The amino acid concentration in fresh milk is higher than in sour milk. (That is already said in the task text.)

\section{Inquiry Skill „Identifies and groups variables”}

- $\quad$ The 'variable' cannot be measured. E: Activated charcoal absorbability.

- The independent and dependent variables have been confused. E: The graphic axes $x$ and $y$ are not denoted, e.g., axis $x$ : speed, and axis $y$ : temperature. (The $\mathrm{x}$ axis should bear the independent variable and the $\mathrm{y}$ axis - the dependent). 
Jelena Volkinsteine, Dace Namsone. Acquisition of Student Scientific Inquiry Skills: Centralised Examination Results in Chemistry

\section{Inquiry Skill „Identifies materials and equipment to use”}

- The list is elaborated very generally, the number and volume of containers are not indicated, the particular substances or the solution concentration are not indicated. E: Different toothpastes, acid solution, chronometer, $\mathrm{H}_{2} \mathrm{O}$, droppers, test-tubes, glass tubes, cylinders, measuring dropper, clean hood.

\section{Inquiry Skill „Plans the procedure”}

- It is written very generally, does not indicate what is required for measuring the dependent variable. E: 1) We are going to install a device for accumulating $\mathrm{O}_{2}$. 2) Gradually we are going to add $\mathrm{H}_{2} \mathrm{O}_{2}$ to catalyzor $\mathrm{MnO}_{2}$. 3) We are going to collect and measure the discharged $\mathrm{O}_{2}$.

- The description does not contain important containers and substances or the mass, volume or concentrations are not indicated accurately, etc. E: 1) Pour hydrogen peroxide in each test-tube. 2) Add catalyser in each test-tube. 3) Observe the $\mathrm{O}_{2}$ accumulation time.

- $\quad$ It is not described how to measure the dependent variable. E: 1) Raw milk is poured in to a beaker and placed in a room temperature. 2) Take a sample using a dropper, place the sample into a test-tube that is placed into a holder and prepare the sample for analysis. 3) Identify the amino acid concentration in the sample and record the data in the table.

- It does not describe how to identify the moment when the reaction ends. E: 1) Using Mora dropper, take a $10 \mathrm{ml}$ milk sample. 2) Add phenolphthalein.

3) Titrate with 0.1M NaOH solution using a dropping glass. 4) Repeat the previously described steps with other milk samples.

Also other inquiry skills demonstrated by the students contained flaws. When demonstrating the inquiry skill „Elaborates a data collection table”, students often do not indicate the table or column name, measurement units or the table contents do not match the measurements planned to be taken during the experiment.

When solving the inquiry task of 2014, the students had the opportunity of demonstrating the experiment evaluation and conclusion drawing skills. The characteristic errors and flaws made by the students when demonstrating these skills:

- Experiment evaluation confused with data analysis;

- The possible error sources of the experiment are not found or the source is indicated formally, without an explanation, e.g., , the human factor"; 
- It is not offered how to eliminate the drawbacks and improve the experiment;

- The conclusion part contained an essential part of the data analysis;

- The conclusion is written as the hypothesis approval, without providing a description.

\section{Student Success Rate in Mastering Inquiry Skills. ILW}

The assessment of the student inquiry skills differs considerably depending on whether the students had demonstrated their inquiry skills during the examination while solving an inquiry task, or while carrying out a inquirybased laboratory work at school. For instance, the student success rate according to the inquiry-based laboratory work record over five years ranges between $75 \%$ and $87 \%$, what is a very high result (Table 9).

Table 9 Inquiry-based Laboratory Work Record Assessment Results

\begin{tabular}{|l|l|l|l|l|}
\hline Year & $\begin{array}{l}\text { Number of Mean } \\
\text { Points }\end{array}$ & \multicolumn{1}{|c|}{$\begin{array}{c}\text { Standard } \\
\text { Deviation }\end{array}$} & \multicolumn{1}{|c|}{$\begin{array}{c}\text { Max. Number of } \\
\text { Points }\end{array}$} & $\begin{array}{c}\text { Success } \\
\text { Rate, \% }\end{array}$ \\
\hline \multicolumn{5}{|c|}{ Posing the Research Question and Planning the Procedure } \\
\hline 2011 & 4.9140625 & 1.593416207 & 6 & 81.9 \\
\hline 2012 & 5.117293233 & 1.432650215 & 6 & 85.3 \\
\hline 2013 & 4.319626168 & 1.77600735 & 6 & 72.0 \\
\hline 2014 & 4.67201426 & 1.613365285 & 6 & 77.9 \\
\hline 2015 & 4.71969697 & 1.633679652 & 6 & 78.7 \\
\hline \multicolumn{7}{|l|}{ Data Collecting, Recording and Processing } \\
\hline 2011 & 5.047991071 & 1.534313809 & 6 & 84.1 \\
\hline 2012 & 5.172932331 & 1.366065045 & 6 & 86.2 \\
\hline 2013 & 4.336448598 & 1.624622833 & 6 & 72.3 \\
\hline 2014 & 4.654188948 & 1.405926649 & 6 & 77.6 \\
\hline 2015 & 4.839015152 & 1.264998285 & 6 & 80.7 \\
\hline \multicolumn{7}{|l|}{ Data and Result Analysis and Evaluation } \\
\hline 2011 & 4.227678571 & 1.854348226 & 6 & 70.5 \\
\hline 2012 & 4.77593985 & 1.596124371 & 6 & 79.6 \\
\hline 2013 & 3.857943925 & 1.603603 & 6 & 64.3 \\
\hline 2014 & 4.106951872 & 1.384598245 & 6 & 75.4 \\
\hline 2015 & 4.503787879 & 1.410177445 & 6 & \\
\hline
\end{tabular}

The skill „Plans the procedure” was examined over the period of four years using the $\mathrm{CE}$ task 3.3, and the obtained results differ considerably from the results of similar skill assessment according to the ILW records (Fig.1). 
Jelena Volkinsteine, Dace Namsone. Acquisition of Student Scientific Inquiry Skills: Centralised Examination Results in Chemistry

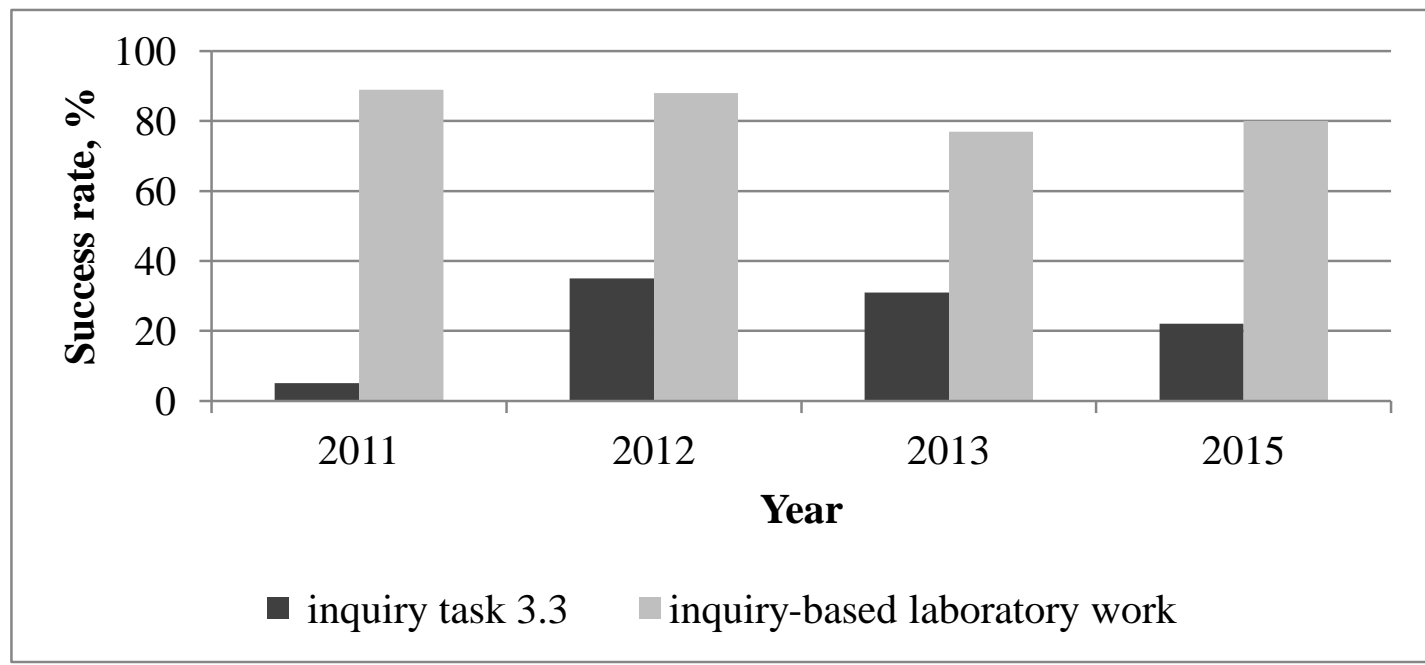

Fig. 1 Comparison of Mastering the Inquiry Skill „Plans the procedure” According to the Inquiry Task and ILW Record Assessment Results

The reasons for higher assessment results in the inquiry-based laboratory work can be several - students carry out the laboratory work during the study process when the skills required for the inquiry work have just been covered. It is possible that 'on their way to examination' the students had insufficient inquiry skill or have never had it. The work cannot be considered as carried out individually, as in the classroom the students are working next to each other in pairs or groups at the presence of their teacher. Different variants of the work are not offered. The issue on the teachers' understanding of the students' scientific inquiry, ability to organise it efficiently and observe objectively is open.

But the most important is that the ILWs organised by the teachers during the study process and used at the CE as a measuring instrument of the student inquiry skills, are not ensured with reliability and validity.

When solving an inquiry task during an examination, the students are working individually. Although not performed in practice, in order to solve this type of task the students have to demonstrate the understanding on what it means to solve a problem in a research way.

\section{Conclusions}

The analysis of the CE results in chemistry shows that in general the national standard requirement on developing the students' inquiry skills is being implemented in the schools of Latvia.

CE inquiry task measures inquiry skills mainly in the area of „Posing the research question and planning the procedure". 
The assessment results show that inquiry tasks have been causing difficulties to students over the period of five years. The students demonstrate the skills ,Formulates the hypothesis, identifies materials and equipment to use, plans the procedure" with drawbacks.

The inquiry skills in the part prepared by the school and in the inquiry task show different achievements: the students' success rate when carrying out a inquiry-based laboratory work at school is considerably higher.

The inquiry-based laboratory work that is organised during the study process at school and the inquiry-based laboratory work record cannot be used as the CE measuring instrument of the inquiry skills.

In order to test the students' inquiry skills, it may be necessary to change the approach to the measuring of the inquiry skills at the CE: to organise the student scientific inquiry during the examination or develop special tasks which contents and amount allow examining the majority of the inquiry skills.

\section{Acknowledgments \\ This research is supported by the National Research Program Project VPP 2014-2017.}

\section{References}

Abd-El-Khalick, F., BouJaoude, S., Duschl, R., Lederman, N. G., Mamlok-Naaman, R., Hofstein, A., \& Tuan, H. (2004). Inquiry in science education: International perspectives. Science Education, 88 (3), 397-419.

Aikenhead, G. (2006). Science Education for Everyday Life. London, ON: Althouse Press.

American Association for the Advancement of Science. (2000). Designs for Literacy. New York: Oxford University Press.

Anderson, R. D. (2002). Reforming science teaching: What research says about inquiry. Journal of Science Teacher Education, 13 (1), 1-12.

Brown, P. L., Abell, S. K., Demir, A., \& Schmidt, F. J. (2006). College science teachers' views of classroom inquiry. Science Education, 90 (5), 784-802.

Buck, L. B., Bretz, S. L., \& Towns, M. H. (2008). Characterizing the Level of Inquiry in the Undergraduate Laboratory. Journal of College Science Teaching, 38 (1), 52-58.

Chiappetta, E. (1997). Inquiry-based science. The Science Teacher, 65 (7), 22-26.

Cohen, L., Manion, L., \& Morrison, K. (2011). Research Methods in Education Paperback. London and NEW YORK: Routledge.

Dewey, J. (1910). Science as subject-matter and as method. Science, 31, 121-127.

Hackett, J. (1998). Inquiry: Both means and ends. The Science Teacher, 65 (6), 35-37.

Hanauer, D. I., Jacobs-Sera, D., Pedulla, M. L., Cresawn, S. G., Hendrix, R. W., \& Hatfull, G. F. (2006). Teaching scientific inquiry. Science, 314 (5807), 1880-1881.

Harlen, W., \& Jelly, S. (1989/1997). Developing science in the primary classroom. Essex, England: Addison Wesley Longman, Ltd.

Hegarty-Hazel, E. (1990). Life in Science Laboratory Classrooms at Tertiary Level. In Hegarty-Hazel, E. (Ed.), The Students Laboratory and the Science Curriculum (pp.357382). London and New York: Routledge. 
Jelena Volkinsteine, Dace Namsone. Acquisition of Student Scientific Inquiry Skills: Centralised Examination Results in Chemistry

Hegarty-Hazel, E. (1990). The students laboratory. In Hegarty-Hazel, E. (Ed.), The Students Laboratory and the Science Currriculum (pp. 3-26). London and New York: Routledge.

Herron, M. D. (1971). Then nature of scientific c inquiry. In J. J. Schwab \& P. F. Brandwein (Eds.), The teaching of science (pp. 3-103). Cambridge, MA: Harvard University Press.

Hofstein, A., Navon, O., Kipnis, M., \& Mamlok-Naaman, R. (2005). Developing students' ability to ask more and better questions resulting from inquiry-type chemistry laboratories. Journal of Research in Science Teaching, 42, 791-806.

Krajcik, J., Mamlok, R., \& Hug, B. (2001). Modern content and the enterprise of science: science education in the 20th century. In L. Corno (Ed.), Education across a century: the centennial volume (pp. 205-238). Chicago, Illinois: National Society for the Study of Education.

Martin-Hansen, L. (2002). Defining inquiry: exploring the many types of inquiry in the science classroom. The Science Teacher, 69 (2), 34-37.

Minstrell, J., \& van Zee, E. (Eds.). (2000). Inquiring into inquiry learning and teaching in science. Washington DC: American Association for the Advancement of Science.

National Research Council. (2001). Educating Teachers of Science, Mathematics, and Technology: New Practices for the New Millennium. Washington, DC: National Academy Press.

Sadeh, I., \& Zion, M. (2009). The Development of Dynamic Inquiry Performances within an Open Inquiry Setting: A Comparison to Guided Inquiry Setting. Journal of Research in Science Teaching, 46 (10), 1137-1160.

Schwab, J. (1960). Enquiry, the science teacher, and the educator. The Science Teacher, 27, 611.

Schwab, J. (1962). The teaching of science as enquiry. In J. J. Schwab \& P. Brandwein (Eds.), The teaching of science (pp. 3-103). Cambridge, MA: Harvard University Press.

Wenning, C. J. (2005). Levels of inquiry: Hierarchies of pedagogical practices and inquiry processes. Journal of Physics Teacher Education Online, 2 (3), 3-11.

Савенков, А. И. (2006). Психологические основы исследовательского подхода к обучению [Psychological Bases for Research Approach in Learning]. Москва: Ось-89.

AQA Science Controlled assessment in GCSE. (2014). Retrieved from http://filestore. aqa.org.uk/support/pdf/AQA-SCIENCE-CONTROLLED-ASSESSMENTLEAFLET.PDF

Cambridge International Examinations. Retrieved from http://www.cie.org.uk

National Centre for Education. (2015). Valsts Pārbaudes darbu programmes [National Test Programmes]. Retrieved from http://visc.gov.lv/vispizglitiba/eksameni/dokumenti/ programmas/2015_2016/vpd_progr_visas_2016.pdf

NECAP Science: Guidelines for the Development of Science Inquiry Tasks. (2008). Retrieved from http://www.ride.ri.gov/Portals/0/Uploads/Documents/Instruction-and-AssessmentWorld-Class-Standards/Science/GDIT-Final-2-15-08.pdf

OECD. (2015). Measuring Student Knowledge and Skills. Retrieved from https://www.oecd.org/pisa/pisaproducts/Draft\%20PISA\%202015\%20Science\%20Fram ework\%20.pdf

The Republic of Latvia Cabinet Regulation No 281 of 21 May 2013. Noteikumi par valsts vispārējās vidējās izglìtības standartu, mācību priekšmetu standartiem un izglìtības programmu paraugiem [Regulations Regarding the State General Secondary Education Standard, Subject Standards and Sample Education programmes]. Retrieved from http://m.likumi.lv/doc.php?id=257229 